NASA Technical Memorandum 83499

\title{
Supersonic Fan Engines for Military Aircraft
}

Leo C. Franciscus

Lewis Research Center

Cleveland, Ohio

Prepared for the

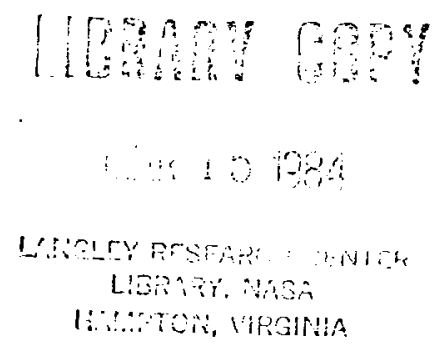

Aircraft Design Systems and Operations Meeting cosponsored by the AIAA and AHS

Fort Worth, Texas, October 17-19, 1983 
Leo C. Franciscus

National Aeronautics and Space Administration

Lewis Research Center

Cleveland, Ohio

\section{ABSTRACT}

Engine performance and mission studies were performed for turbofan engines with supersonic through-flow fans. A Mach 2.4 CTOL aircraft was used in the study. Two missions were considered: a long range penetrator mission and a long range intercept mission. The supersonic fan engine is compared with an augmented mixed flow turbofan in terms of mission radius for a fixed takeoff gross weight of 75,000 lbm. The mission radius of aircraft powered by supersonic fan engines could be 15 percent longer than aircraft powered with conventional turbofan engines at moderate thrust to gross weight ratios. The climb and acceleration performance of the supersonic fan engines is better than that of the conventional turbofan engines.

\section{NOMENCLATURE}

$\begin{array}{ll}\text { BPR } & \text { bypass ratio } \\ \text { CET } & \text { combustor exit temperature, oR } \\ \text { F } & \text { thrust } \\ \text { FPR } & \text { fan pressure ratio } \\ \mathrm{ft} & \text { feet } \\ \mathrm{g} & \text { gravitational acceleration, } 32.174 \\ & \text { ft/sec } \\ \mathrm{hr} & \text { hour } \\ \mathrm{lbm} & \text { pound mass } \\ \mathrm{lbf} & \text { pound force } \\ \mathrm{M} & \text { Mach number } \\ \mathrm{nmi} & \text { nautical mile } \\ \text { OPR } & \text { engine overall pressure ratio } \\ \text { sfC } & \text { specific fuel consumption lbm/hr/lbf } \\ \text { TAUG } & \text { augmentor temperature, OR } \\ \text { TOGW } & \text { takeoff gross weight, lbm } \\ U & \text { fan tip speed, ft/sec } \\ \text { W } & \text { weight, lbm }\end{array}$

\section{Subscripts}

$\begin{array}{ll}\text { AB } & \text { absolute } \\ \text { ENG } & \text { engine } \\ \text { MAX } & \text { maximum } \\ 0 & \text { ambient }\end{array}$

\section{INTRODUCT ION}

The intent of the Supersonic Cruise Aircraft Pesearch Program (SCR) sponsored by NASA (19721981) was to identify and investigate areas requiring new and improved technology that would lead to substantial improvements in performance. 1 The program was focused mainly on commercial supersonic cruise aircraft. A number of advanced engine concepts were identified by the industry as being attractive for a commercial SST.2-5 The supersonic through-flow fan engine was proposed by Advanced Technology Laboratories, Inc. and studied by them under
NASA contract. The results of their studies showed that this type of engine may be a more efficient powerplant for supersonic cruise aircraft than any of the other types being considered.6 Additional in-house studies at Lewis showed similar attractive results. 7

For the long supersonic cruise range considered in the SCR studies, a large part of the advantage of this engine is attributed to improved engine SFC's at supersonic cruise and to a lesser extent to the increased dry thrust to engine weight.

A preliminary study of the use of supersonic through-flow fan engines for CTOL military aircraft was initiated to indicate if military aircraft would benefit by this engine concept. The initial results of this study are presented in this paper.

The study encompassed aircraft with missions requiring extended supersonic cruise ranges. Two engine types were included in the study: a supersonic through-flow fan engine and a conventional mixed flow augmented turbofan. The engines are compared on the basis of mission radius for a fixed takeoff gross weight. The effect of constraints such as time to climb on the engine comparisons are shown.

\section{DESCRIPTION OF THE ENGINES}

The engine concepts are shown in Figure 1 . Engine cycle characteristics and weight are shown in Table $I$.

The supersonic fan engine is similar to a two spool conventional turbofan except for the inlet and fan. The supersonic fan is a supersonic through-flow fan stage, i.e., supersonic absolute Mach numbers at the fan face and stator exit. The supersonic fan would lead to improvements in the overall propulsion system. These improvements are a reduction in fan weight (single-stage vs. multi-stage), reductions in inlet losses (at supersonic flight), and inlet weight, and more flexibility in matching the engine cycle to the airplane thrust requirements.

The inlet losses and weight are lower than a conventional inlet because little diffusion (velocity decrease) of the air is required. As shown in figure 2, the fan face absolute Mach numbers range from 1 at takeoff to values slightly less than free stream during supersonic flight. At Mach 2.4 cruise, for example, the fan face Mach number is about 2 and the diffusion of the air is about $400 \mathrm{ft} / \mathrm{sec}$. In a conventional inlet, the diffusion is about 1,500 $\mathrm{ft} / \mathrm{sec}$. Therefore, less boundary layer bleed (and associated bleed $\mathrm{drag}$ ) is required to 
accomplish the lower diffusion for the supersonic fan. The lower diffusion also reduces spillage drag. These drag reductions result in improvements in the overall inlet performance shown in figure 3.

Since the supersonic fan exit Mach numbers are always supersonic (fig. 2) the duct nozzle could be mechanically simpler (no throat required) than a conventional $C-D$ nozzle. This could lead to a more efficient and lighter nozzle than a conventional nozzle. However, because the fan discharge Mach numbers are supersonic, a diffuser is required for the engine core air (fig. 1). Only the core of this engine is equipped with an augmentor. The conventional engine used for comparison is a two spool mixed flow augmented turbofan (fig. 1). The same technology was assumed for the cores of both engines.

\section{METHOD OF ANALYSIS}

The study reflected differences in engine thrust and SFC, pod drag, and propulsion system weight. Mission performance calculations were made to determine mission radius as a function of sea level static thrust/gross weight for a fixed takeoff gross weight and payload.

Two missions were selected to study the engines for a variety of flight conditions and requirements. The mission profiles are illustrated in figure 4. Mission $A$ is a predominately supersonic mission similar to a penetrator type mission and mission $B$ would be similar to a supersonic intercept with a subsonic loiter capability. The total range is the sum of the climb/acceleration, cruise, and letdown ranges. Fuel reserves include an enroute contingency of 5 percent of the mission fuel and provision for a 20 minute loiter.

The airplane used is the study is an arrow wing vehicle with podded engines. The airplane gross weight ( 75000 LBM), payload (6000 LBM), and operating empty weight less propulsion weight remained fixed so that the mission radius varied with changes in engine performance and weight.

The installed engine performance for the engines was computed with the engine cycle computer program of reference 8 which performs cycle calculations, design, and off-design on a component by component basis. Except for the supersonic fan, the component aerodynamic characteristics, efficiencies, and cooling requirements for conventional fans, compressors, turbines, combustors, etc. used in the program were the same for both engines. For the supersonic fan a baseline design adiabatic efficiency of 0.85 was assumed and the aerodynamics were obtained from reference 6 . Installation losses included inlet and nozzle drags and nacelle friction drag.

The airflow schedule and performance of a Mach 2.4 translating centerbody inlet was used for the conventional turbofan engine. The inlet drag penalties shown in figure 3 include spillage, bypass, and bleed. The inlet for the supersonic fan would be a low compression device. The pressure rise across the inlet at Mach 2.4 would be about 2 compared to 10 for the conventional inlet. Preliminary performance estimates of the supersonic fan inlet were taken from reference 7 . The core diffuser is different from a conventional inlet. Except for starting, inlet Mach numbers are always supersonic ranging from 2 at takeoff to 3 at Mach 2.4 cruise (fig. 2). Because no data exists for this type of diffuser, a typical Mach 3 inlet pressure recovery of 0.85 was assumed. This component would be a required area of research.

Propulsion system weight estimates for the conventional turbofan and the core of the supersonic fan engines were calculated using the methods from reference 9 . For the supersonic fan and its inlet, nozzle, and core diffuser, the weights were scaled from the data of reference 7 .

\section{RESULTS AND DISCUSSION}

Engine performance and weight - As mentioned previously, the operating characteristics of the supersonic fan lead to improved propulsion system performance. In addition to the low inlet losses ( $f i g .3$ ) the cycle can be matched better to the aircraft thrust requirements. In the conventional bypass engine the bypass ratio increases with flight Mach number from 1 at sea level static to 1.3 at Mach 2.4. This leads to lower dry thrust and an increase in afterburning to obtain the required thrust, resulting in SFC penalties. For the supersonic fan engine the bypass ratio decreases from 1 at sea level static to 0.7 at Mach 2.4. However, since the bypass air of the supersonic fan engine is supersonic, burning in the duct flow would entail heavy losses. Therefore, only the core nozzle has an afterburner. For the same thrust requirement, the supersonic fan engine would be a larger engine size than the conventional turbofan.

Figure 5 shows a comparison of the SFC's of the two engines at Mach 2.4. Both engines are sized for a sea level thrust to airplane gross weight ratio of 0.9 ( $F=33750$ lbf). The sea level static airflow of the supersonic fan engine is $370 \mathrm{lb} / \mathrm{sec}$ compared to $260 \mathrm{lb} / \mathrm{sec}$ for the conventional turbofan (about 40 percent larger). However, the maximum dry thrust at Mach 2.4 is nearly twice that of the conventional engine. As indicated in figure 5 , the SFC's of the supersonic fan engine are lower than those of the conventional engine. At the cruise operating point shown in the figure, the SFC of the supersonic fan engine is 10 percent lower than that of the conventional turbofan.

Figure 6 shows the engine performance for the Mach 0.8 loiter of Mission B ( $f i g .4$ ). Both engines would operate at low throttle. For the operating points shown in the figure, the conventional turbofan would have somewhat betteI performance than the supersonic fan because it is throttled back less.

Figure 7 shows the climb/acceleration performance of the two engines sized for the same sea level static thrust loading. As mentioned before the supersonic fan diameter would be 
larger than that of the conventional turbofan for the same sea level static thrust because it has a lower thrust per unit airflow. As shown in figure 7, the acceleration/climb thrust of the supersonic fan engine is greater than that of the conventional turbofan and the SFC's are significantly better. As seen in figure 8 , the supersonic fan engine would be about 30 percent lighter than the conventional turbofan for the same sea level static airflow. For the same sea level static thrust, the propulsion system weights are about the same.

Mission studies - For Mission A the major part of the fuel is used during supersonic flight. Even though the climb/acceleration thrust of the supersonic fan engine is greater than that of the conventional turbofan (for the same thrust to weight airplane takeoff gross weight ratio) and the SFC's are lower (fig. 7). The savings in fuel over this portion of the mission are small. The propulsion system weights are also about equal. The supersonic fan engine achieves the high mission radii shown in figure 9 due to lower SFC's at Mach 2.4 cruise (fig. 5). The major improvements are at thrust to weight ratios of 0.4 to 0.6 corresponding to take-off distance of 2500 to 1700 feet. At higher values of thrust to weight the propulsion system weight for both engines becomes large. Also, the wing loading (TOGW/S) due to increasing wing size, decreases with increasing thrust to airplane weight ratios to achieve the 39 manuever and wing weight increases. The fuel available for supersonic cruise becomes small for both engines at high thrust to weight ratios. The mission radius is about equal for both engines at a thrust to weight ratio of 1 . However, a five minute time to climb requirement could be achieved by the supersonic fan engine at a much higher mission radius than is achievable by the conventional turbofan engine ( $F / W=0.65$ vs. 0.95 ( $f i g .9)$ ).

For Mission $B$, the decrease in mission radius with increasing thrust to gross weight ratios is much the same as for Mission $A$ (increasing engine and wing weights). However, above thrust to weights ratios of 0.7 the conventional turbofan engine achieves higher radii than the supersonic fan engine. This is due to the 60 minute loiter at Mach 0.8. The conventional turbofan has better SFC's at loiter (fig. 6). At the higher thrust to weight ratios where the total available fuel is decreasing, the saving in fuel at loiter becomes more critical. However, the supersonic fan engine achieves the five minute time to climb requirement at a higher radius than the conventional turbofan for Mission $\mathrm{B}$ also.

\section{CONCLUDING REMARKS}

The supersonic through-flow turbofan could be an attractive engine for advanced military aircraft that have a large supersonic flight segment. It can achieve higher climb/acceleration thrust than the conventional engine for about the same engine weight due to the savings in inlet and nacelle weights and its variable bypass operating characteristics which improves engine lapse rate. Although only a few mission requirements were considered in this study, the results indicate that the supersonic fan engine can meet these requirements with a better mission radius than is achievable with a conventional augmented turbofan.

These preliminary results are attractive enough to suggest conducting a more in-depth analysis of this engine. Such an analysis should include an extensive study of the fan aerodynamics and a detailed mechanical study of the engine.

\section{REFERENCES}

1. Fishbach, L. H., Stitt, L. E., Stone, J. R., and Whitlow, J. B. Jr., "NASA Research in Supersonic Propulsion - A Decade of Progress," NASA-TM-82862, 1982

2. Howlett, R. A. and Hunt, R. B., "VSCE Technology Definition Study," Pratt and Whitney Aircraft, East Hartford, CT, PWA-5630-11, Aug. 1979. (NASA-CR-159730)

3. Allan, R. D., Johnson, J. E., Joy, W., Brown, R. H., and Barrial, H. J., "Engine Cycle Studies Program," Ceneral Electric Company, Cincinnati, OH, R8OAEG428, Aug. 1980. (NASA-CR-159500)

4. Sabatella, J. A., ed., "Advanced Supersonic Propulsion Study," Pratt and Whitney Aircraft, East Hartford, CT, PWA-MM-4871, Jan. 1974. (NASA-CR-134633)

5. Szeliga, R. and Allan, R. D., "Advanced Supersonic Technology Propulsion System Study," Ceneral Electric Company, Cincinnati, OH, R74AEG330, July 1974. (NASA-CR-143634)

6. Trucco, H., "Study of Variable Cycle Engines Equipped with Supersonic Fans," Advanced Technology Laboratories, Inc., Westbury, NY, ATL-TR-201, Sep. 1975. (NASA-CR-134777)

7. Franciscus, L. C., "Supersonic Through-Flow Fan Engines for Supersonic Cruise Aircraft," NASA-TM-78889, 1978.

8. Fishbach, L. H. and Caddy, M. J., "NNEP--The Navy-NASA Engine Program," NASA-TM-X-71857, 1975.

9. Onat, E. and Klees, G. W. "A Method to Estimate Weight and Dimensions of Large and Small Gas Turbine Engines, Boeing Military Airplane Development, Seattle, WA, Jan. 1979." (NASA CR-159481). 

TABLE I. - ENGINE CHARACTERISTICS

\begin{tabular}{|l|c|c|}
\hline Characteristic & $\begin{array}{c}\text { Supersonic } \\
\text { fan } \\
\text { turbofan }\end{array}$ & $\begin{array}{c}\text { Mixed } \\
\text { flow } \\
\text { turbofan }\end{array}$ \\
\hline BPR & 1.0 & 1.0 \\
OPR & 20.0 & 20.0 \\
FPR & 3.0 & 4.0 \\
CETMAX & $3900 \mathrm{R}$ & $3900 \mathrm{R}$ \\
TAUGMAX & $3900 \mathrm{R}^{*}$ & $3900 \mathrm{R}$ \\
F/WENG & 7.8 & 7.8 \\
\hline
\end{tabular}

*Core nozzle only. 



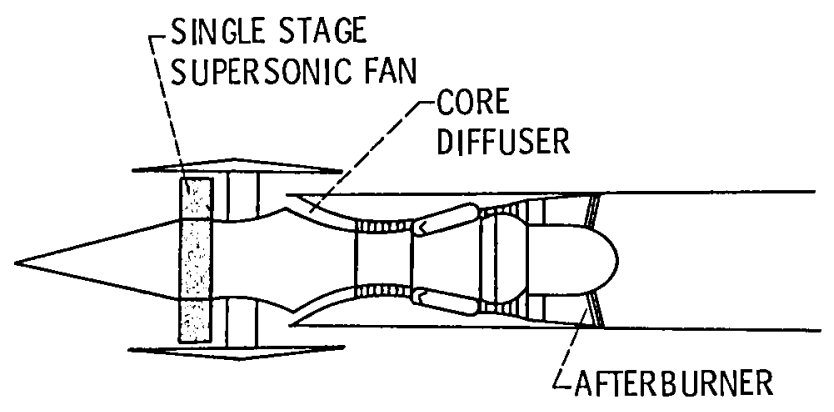

SUPERSONIC FAN TURBOFAN

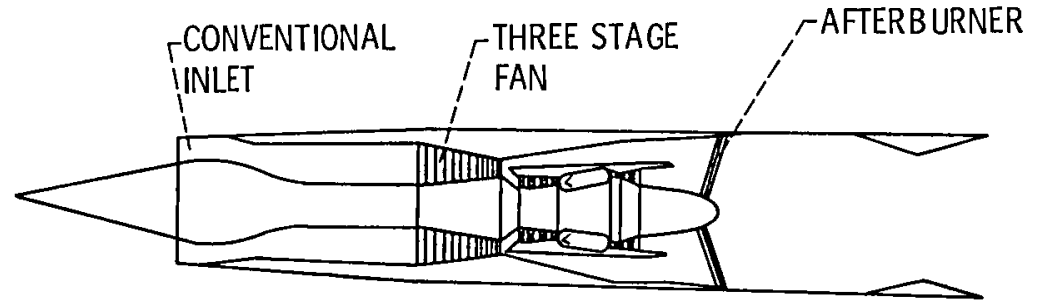

CONVENTIONAL TURBOFAN

Figure 1. - Engine concepts.
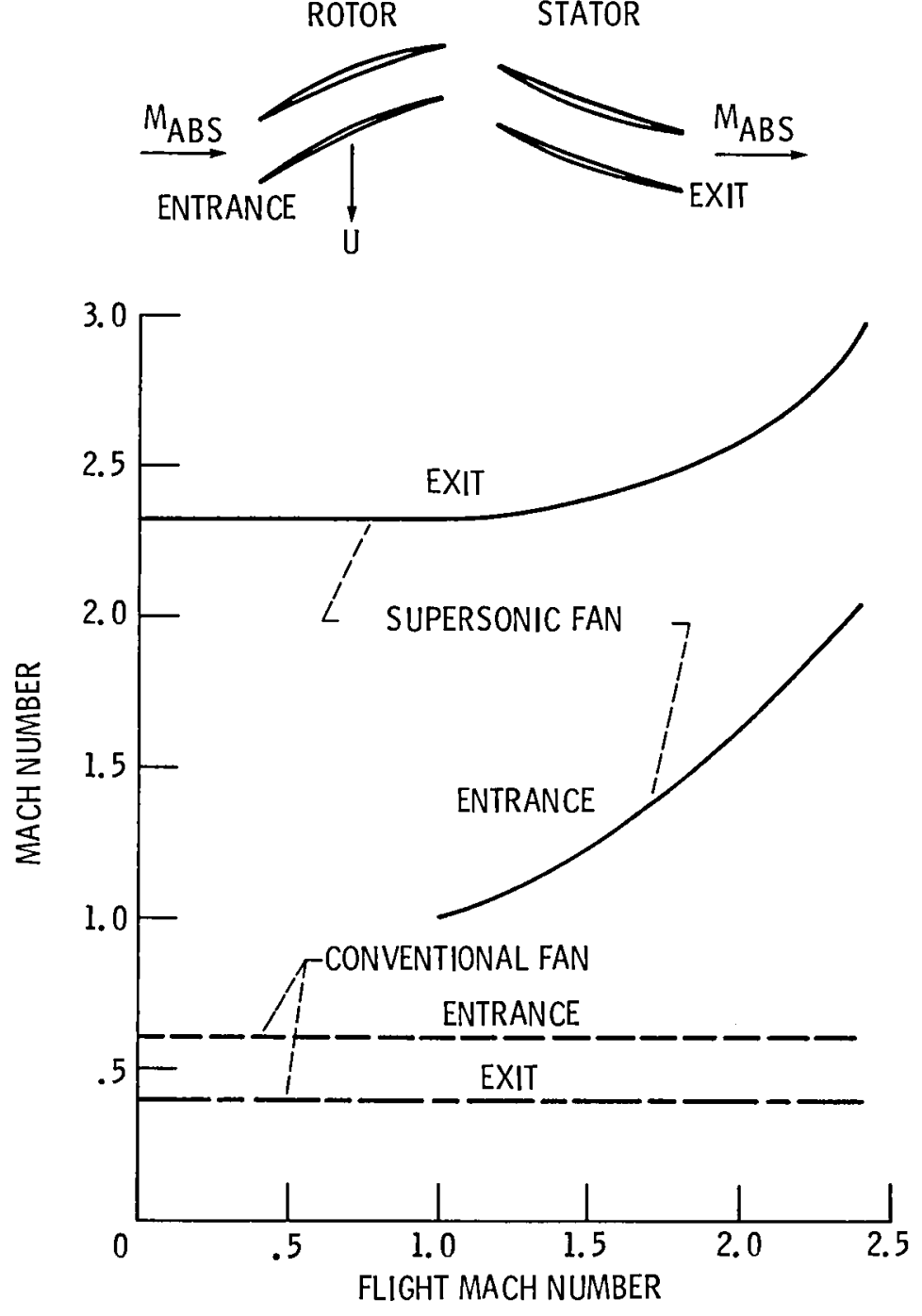

Figure 2. - Variation of fan entrance and exit absolute Mach numbers with flight Mach number. 


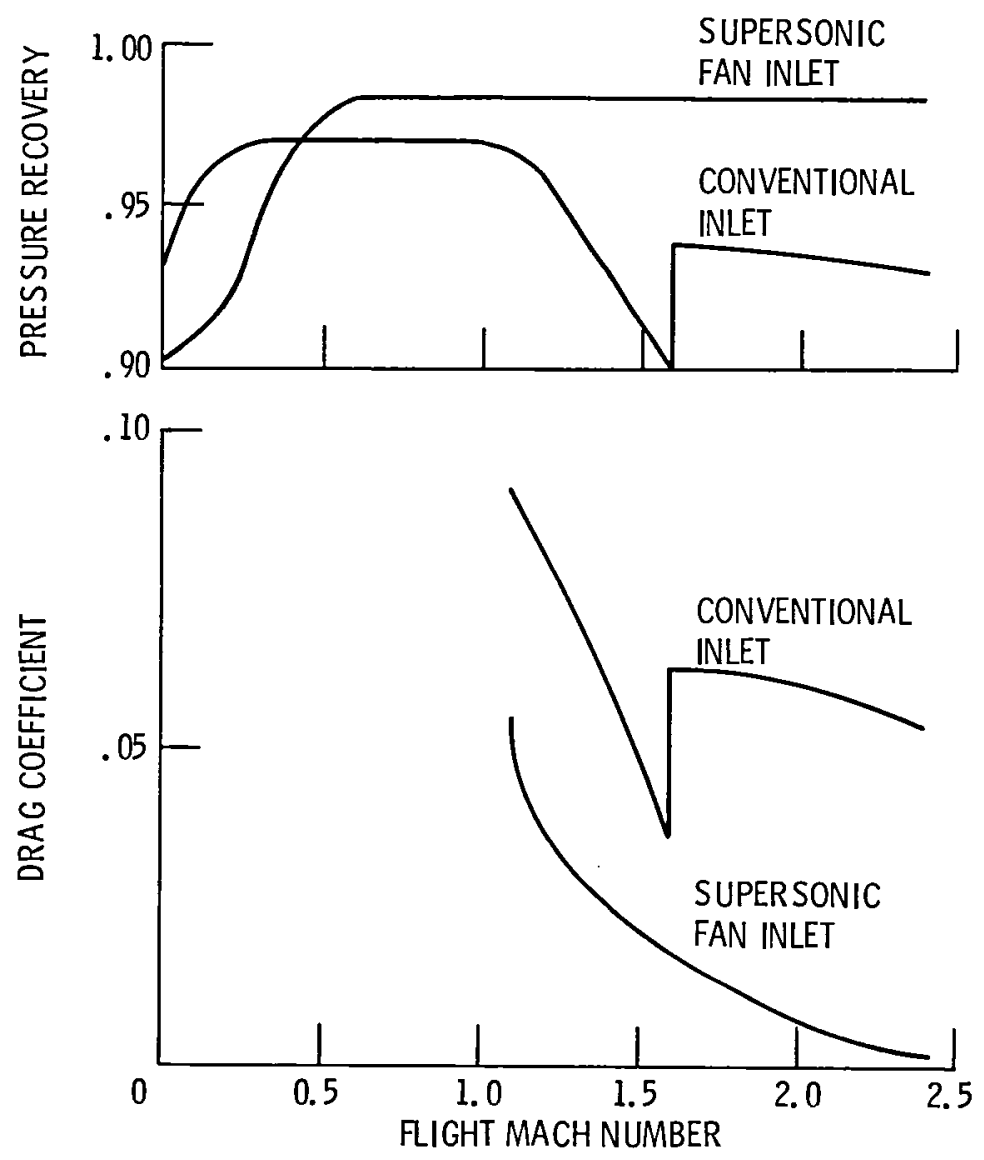

Figure 3. - Comparison of the supersonic fan inlet performance with the conventional inlet performance. 


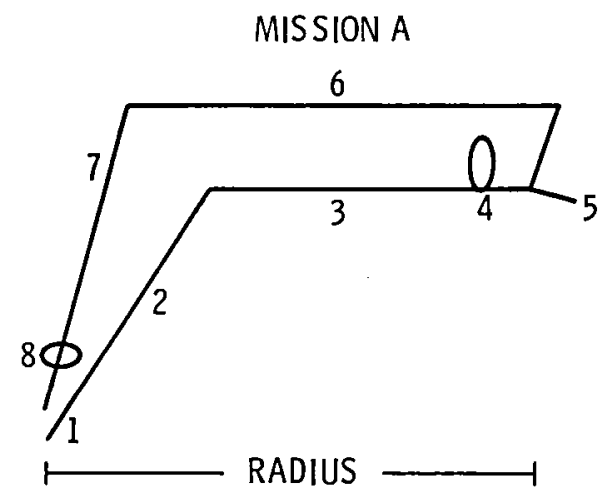

1. TAKEOFF

2. CLIMB ; MAX POWER

3. CRUISE; MACH 2.4; OPTIMUM ALTITUDE

4. 11/2 TURNS; MINIMUM RADIUS; MACH 2.4; MAX POWER LEVEL FLIGHT

5. LAUNCH MISSILES

6. CRUISE; MACH 2.4; OPTIMUM ALTITUDE

7. FLIGHT IDLE DESCENT

8. LOITER $20 \mathrm{~min} ; \mathrm{MACH} 0.45 ; 15000 \mathrm{ft}$

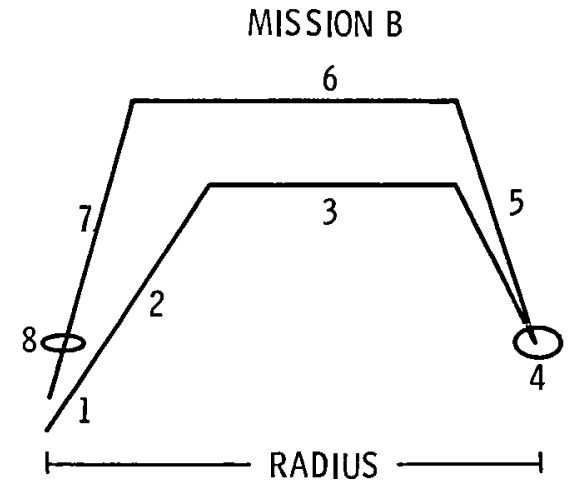

1. TAKEOFF

2. CLIMB ; MAX POWER

3. CRUISE; MACH 2.4; OPTIMUM ALTITUDE

4. 60-MINUTE LOITER; MACH 0.8; OPTIMUM ALTITUDE

5. CLIMB; MAX POWER

6. CRUISE; MACH 2.4; OPTIMUM ALTITUDE

7. FLIGHT IDLE DESCENT

8. LOITER $20 \mathrm{~min}$; MACH $0.45 ; 15000 \mathrm{ft}$

REQUIREMENTS

PAYLOAD - $6000 \mathrm{lb}$

3 G MANEUVER; SUPERSONIC; MACH 2.4

5 min TIME TO CLIMB; SEA LEVEL TO $50000 \mathrm{ft}$; MACH 2

Figure 4. - Mission profiles. 


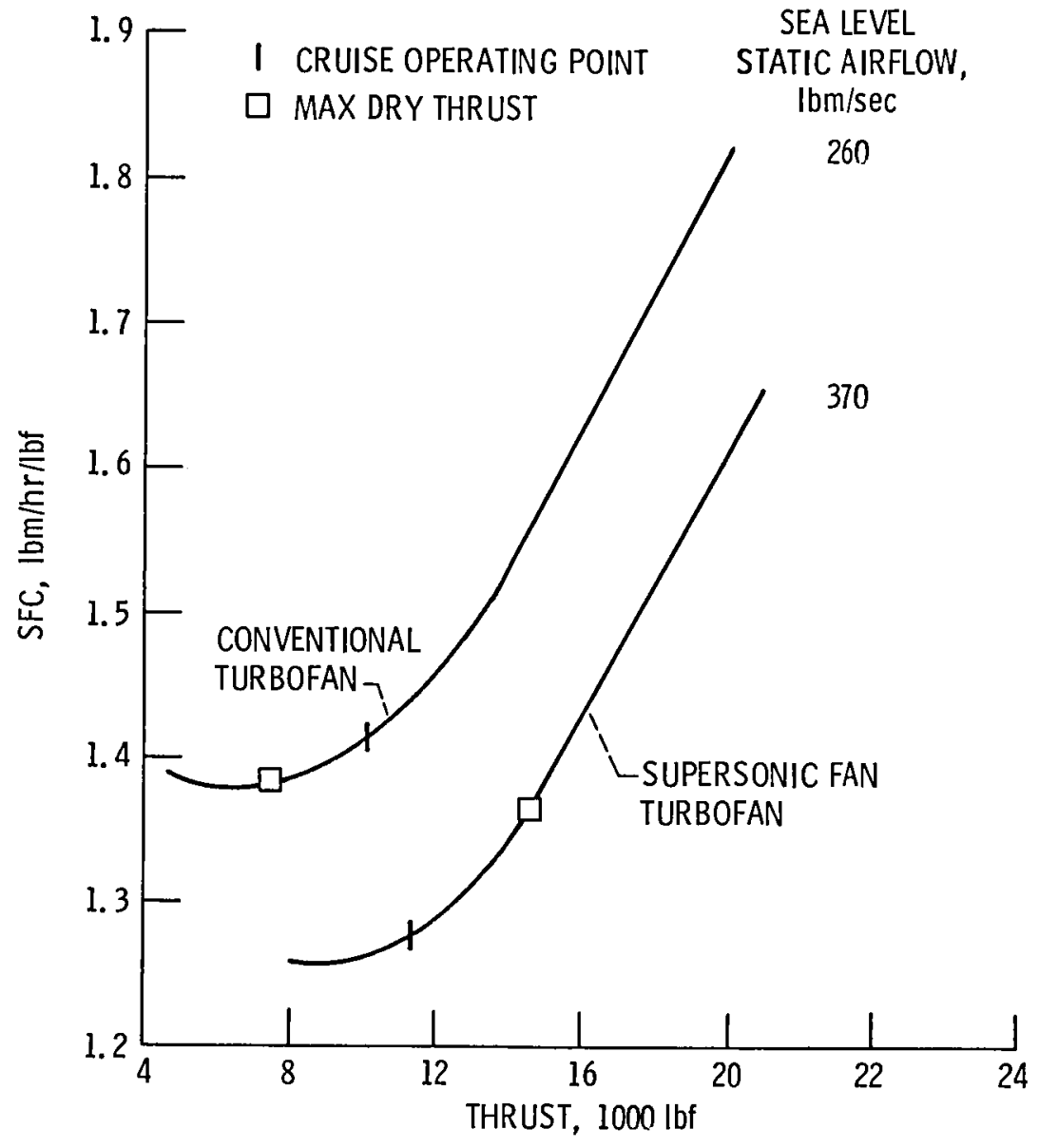

Figure 5. - Comparison of the supersonic fan turbofan and conventional turbofan engine performance at Mach 2.4; altitude $53000 \mathrm{ft}$; sea level static thrust/gross weight -0.9 .

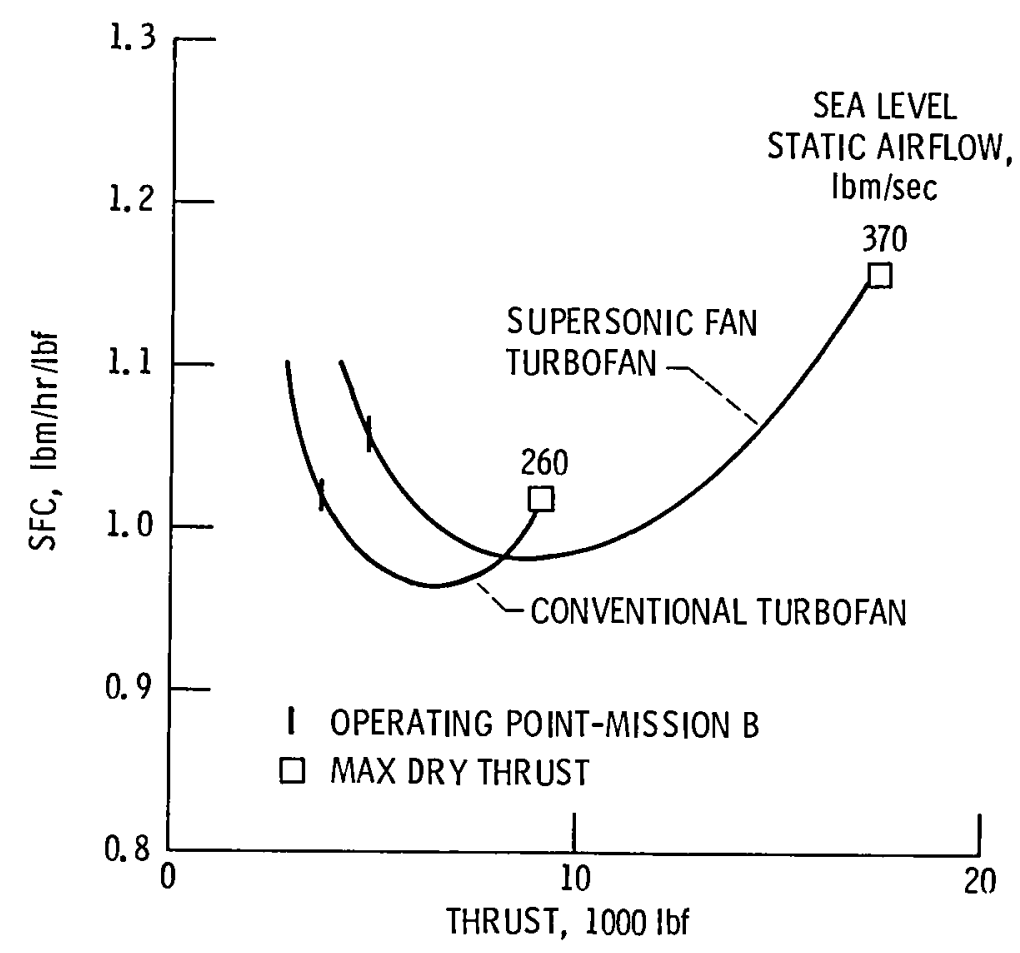

Figure 6. - Comparison of the supersonic fan turbofan and the conventional turbofan engine performance at Mach 0.8; altitude - $21000 \mathrm{ft}$; sea level static thrust/ gross weight -0.9 . 

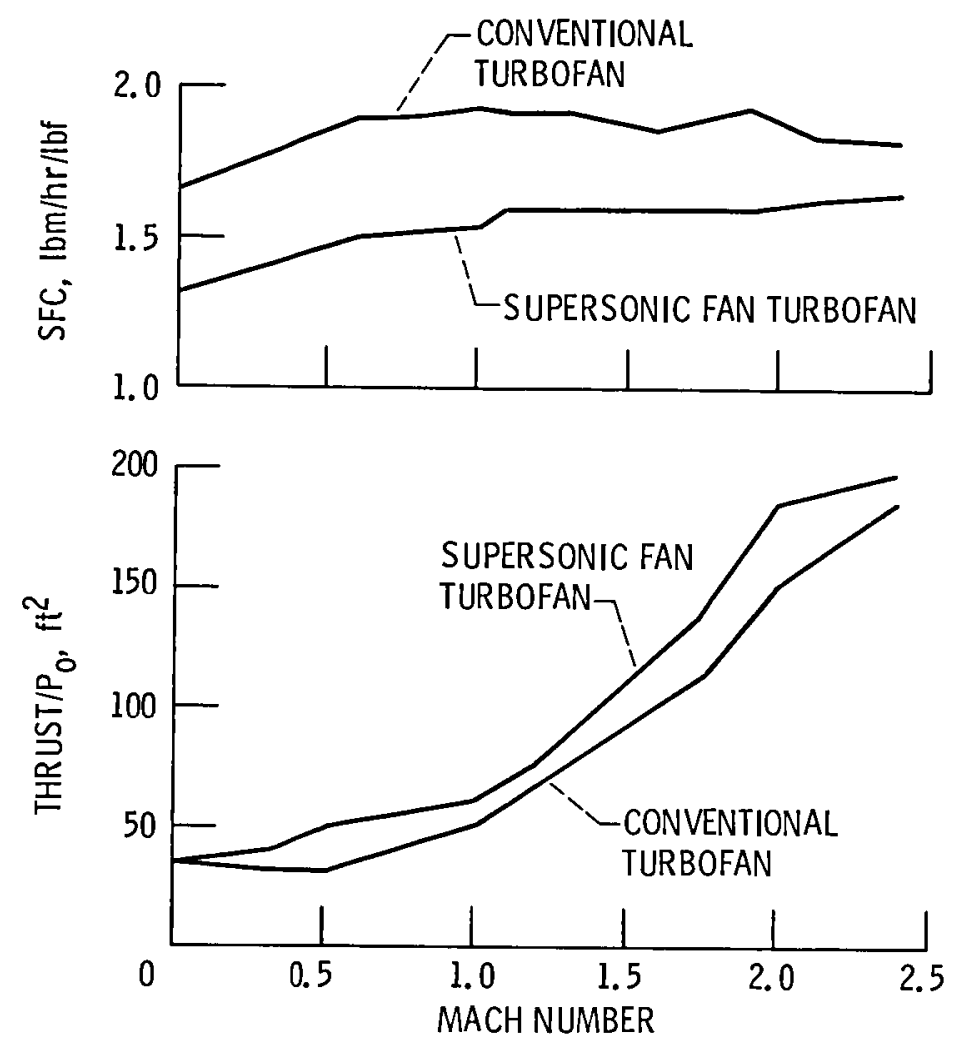

Figure 7. - Climb/acceleration engine performance of the supersonic fan turbofan and the conventional turbofan; sea level static thrust/gross weight-0.9.

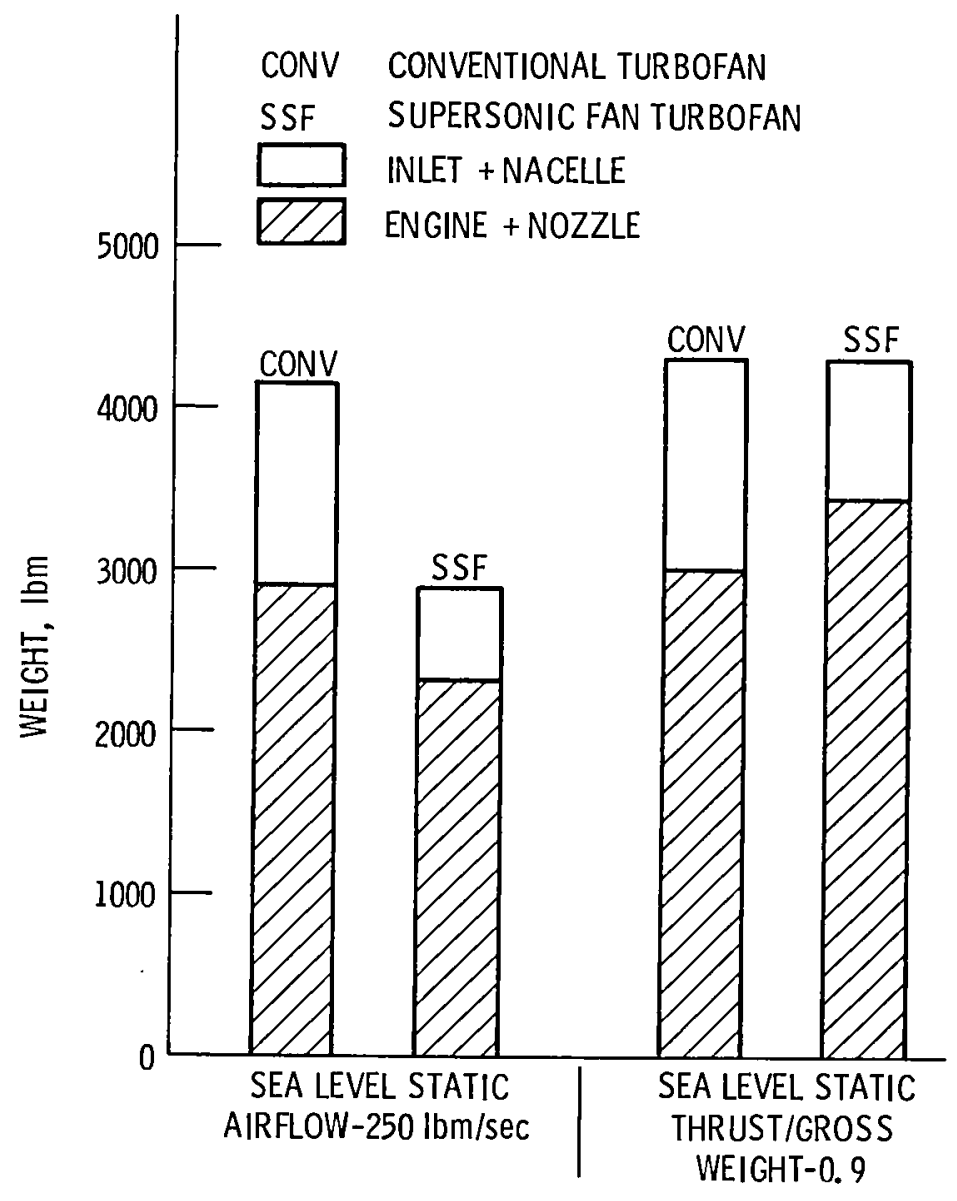

Figure 8. - Installed propulsion system weight. 


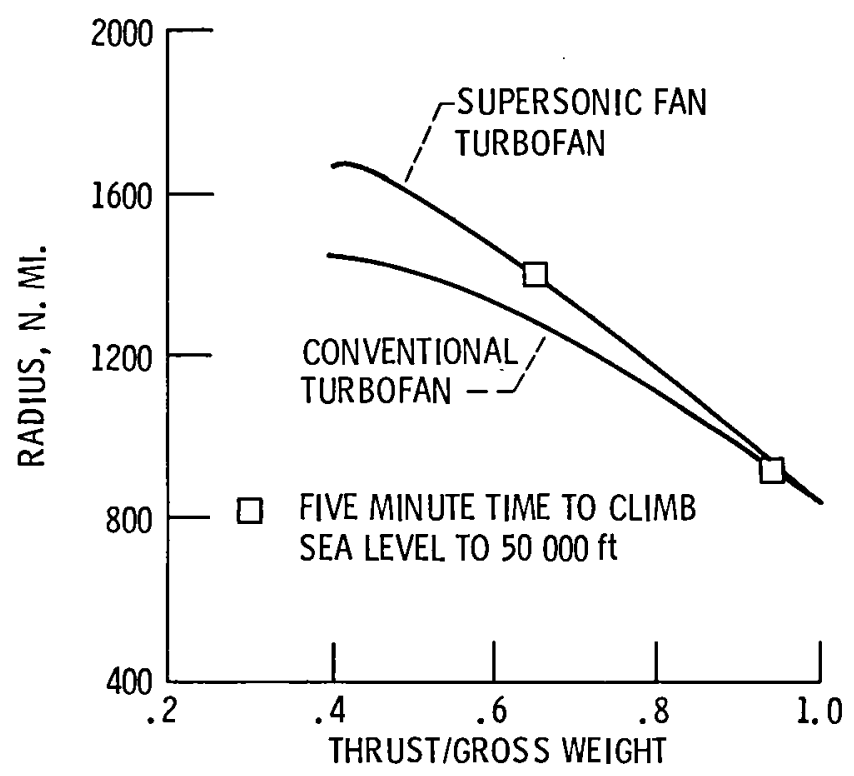

Figure 9. - Comparison of mission performance of the supersonic fan turbofan and the conventional turbofan for mission A; TOGW $75000 \mathrm{lbm}$.

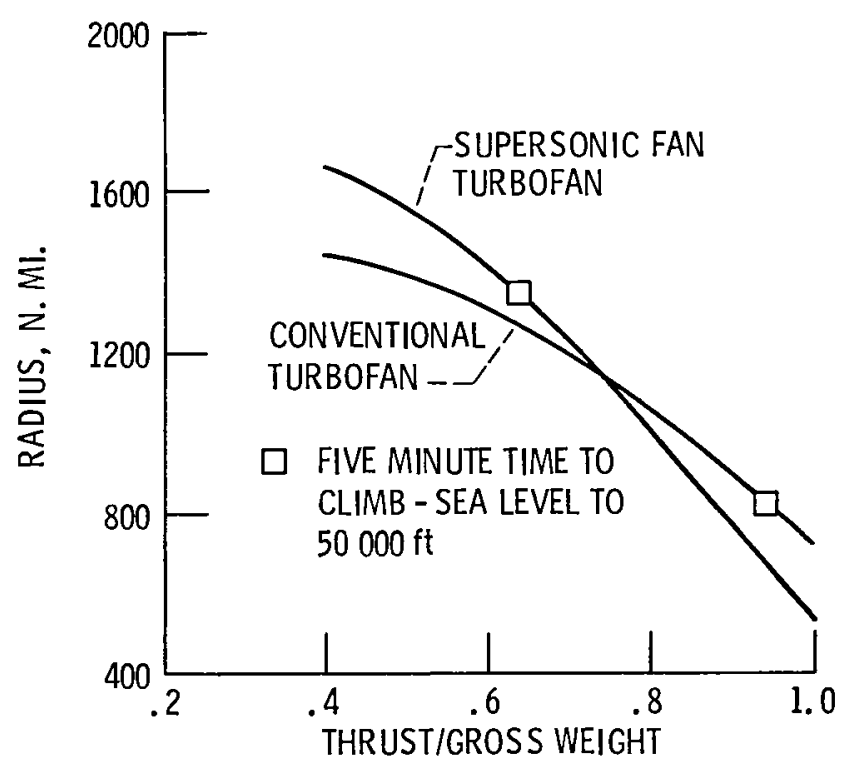

Figure 10. - Comparison of mission performance of the supersonic fan turbofan and the conventional turbofan for mission $B$; TOGW $75000 \mathrm{lbm}$. 


\begin{tabular}{|c|c|c|c|}
\hline $\begin{array}{l}\text { 1. Report No. } \\
\text { NASA TM-83499 }\end{array}$ & 2. Government Accession No. & \multicolumn{2}{|c|}{ 3. Reclplent's Catalog No. } \\
\hline \multirow{2}{*}{\multicolumn{2}{|c|}{$\begin{array}{l}\text { 4. Title and Subtltle } \\
\text { Supersonic Fan Engines for Military Aircraft }\end{array}$}} & \multicolumn{2}{|l|}{ 5. Report Date } \\
\hline & & \multicolumn{2}{|c|}{$\begin{array}{l}\text { 6. Performing Organlzation Code } \\
505-40-82\end{array}$} \\
\hline \multirow{2}{*}{\multicolumn{2}{|c|}{$\begin{array}{l}\text { 7. Author(s) } \\
\text { Leo C. Franciscus }\end{array}$}} & \multicolumn{2}{|c|}{$\begin{array}{l}\text { 8. Performing Organization Report No. } \\
\text { E-1833 }\end{array}$} \\
\hline & & \multicolumn{2}{|l|}{ 10. Work Unit No. } \\
\hline \multirow{3}{*}{\multicolumn{2}{|c|}{$\begin{array}{l}\text { 9. Performing Organlzation Name and Address } \\
\text { National Aeronautics and Space Administration } \\
\text { Lewis Research Center } \\
\text { Cleveland, Ohio } 44135\end{array}$}} & & \\
\hline & & \multicolumn{2}{|c|}{ 11. Contract or Grant No. } \\
\hline & & \multicolumn{2}{|c|}{$\begin{array}{l}\text { 13. Type of Report and Perlod Covered } \\
\text { Technical Memorandum }\end{array}$} \\
\hline \multicolumn{2}{|c|}{$\begin{array}{l}\text { 12. Sponsoring Agency Name and Address } \\
\text { National Aeronautics and Space Administration } \\
\text { Washington, D.C. } 20546\end{array}$} & \multicolumn{2}{|c|}{ 14. Sponsoring Agency Code } \\
\hline \multicolumn{4}{|c|}{$\begin{array}{l}\text { 15. Supplementary Notes } \\
\text { Prepared for the Aircraft Design Systems and Operations Meeting cosponsored by the } \\
\text { AIAA and AHS, Fort Worth, Texas, October 17-19, 1983. }\end{array}$} \\
\hline \multicolumn{4}{|c|}{$\begin{array}{l}\text { 16. Abstract } \\
\text { Engine performance and mission studies were performed for turbofan engines with } \\
\text { supersonic through-flow fans. A Mach } 2.4 \text { CTOL aircraft was used in the study. } \\
\text { Two missions were considered: a long range penetrator mission and a long range } \\
\text { intercept mission. The supersonic fan engine is compared with an augmented mixed } \\
\text { flow turbofan in terms of mission radius for a fixed takeoff gross weight of } \\
75,000 \text { lbm. The mission radius of aircraft powered by supersonic fan engines } \\
\text { could be } 15 \text { percent longer than aircraft powered with conventional turbofan } \\
\text { engines at moderate thrust to gross weight ratios. The climb and acceleration } \\
\text { performance of the supersonic fan engines is better than that of the conventional } \\
\text { turbofan engines. }\end{array}$} \\
\hline $\begin{array}{l}\text { 17. Key Words (Suggested by Author(s)) } \\
\text { Super sonic } \\
\text { Military } \\
\text { Aircraft } \\
\text { Turbine engine }\end{array}$ & $\begin{array}{r}\text { 18. Dist! } \\
\text { Un } \\
\text { ST }\end{array}$ & $\begin{array}{l}\text { d }- \text { unlimit } \\
\text { ry } 07\end{array}$ & \\
\hline $\begin{array}{l}\text { 19. Securlty Classif. (of this report) } \\
\text { Unclassified }\end{array}$ & $\begin{array}{l}\text { Securlty Classif. (of thls page) } \\
\text { Unclass ified }\end{array}$ & 21. No. of pages & 22. Price $\theta^{*}$ \\
\hline
\end{tabular}

•For sale by the National Technical Information Service, Springfield, Virginia 22161 

National Aeronautics and Space Administration

Washington, D.C.

20546

Official Business

Penaley for Private Use, $\$ 300$
SPECIAL FOURTH CLASS MAIL BOOK

Postage and Fees Paid National Aeronautics and Space Administration NASA-45 